\title{
Potential spread and economic impact of invasive Drosophila suzukii in Brazil
}

\author{
Norton Polo Benito( ${ }^{(1)}$, Marcelo Lopes-da-Silva(1) and Régis Sivori Silva dos Santos ${ }^{(2)}$
}

\begin{abstract}
(1)Embrapa Recursos Genéticos e Biotecnologia, Parque Estação Biológica, Avenida W5 Norte (Final), Caixa Postal 02372, CEP 70770-917 Brasília, DF, Brazil. E-mail: norton.benito@embrapa.br, marcelo.lopes.silva@embrapa.br (2)Embrapa Uva e Vinho, Rua Livramento, no 515, Caixa Postal 130, CEP 95700-000 Bento Gonçalves, RS, Brazil. E-mail: regis.sivori@embrapa.br
\end{abstract}

\begin{abstract}
The objective of this work was to outline the potential distribution and economic impact of Drosophila suzukii (Diptera: Drosophilidae), a recent invasive pest, in Brazil. Two maps of the potential establishment of the species were drawn based on the ecoclimatic index (EI), which uses the following thermal requirements for the species: with thermal stress, most restrictive scenario for spread; and without thermal stress. The EI was classified into four ranges: unfavorable, $\leq 25 \%$; less favorable, $>25$ to $\leq 50 \%$; favorable, $>50$ to $\leq 75 \%$; and highly favorable, $>75 \%$. Economic losses were estimated based on the most restrictive map. The highly favorable areas were overlapped with those of the maps of production data for each possible host (apple, grape, peach, persimmon, fig, and pear). Considering these six hosts, the overlap between the highly favorable and the production areas varied from $45.5 \%$ (grape) to $98.3 \%$ (apple). However, the monetary estimation of the potential losses in the worst case scenario (no control measures) was possible only for figs and peaches. Southern Brazil is the most climatically favorable area for D. suzukii development and where potential economic losses are expected to be the greatest. Maximum average temperatures $\left(>30^{\circ} \mathrm{C}\right)$ are the main ecological factor to limit D. suzukii spread in Brazil.
\end{abstract}

Index terms: adaptation, biogeography, bioinvasion, exotic species, spotted wing drosophila.

\section{Dispersão e impacto econômico potenciais da invasora Drosophila suzukii no Brasil}

\begin{abstract}
Resumo - O objetivo deste trabalho foi delinear a distribuição e o impacto econômico potenciais de Drosophila suzukii (Diptera: Drosophilidae), recente praga invasora, no Brasil. Foram feitos dois mapas de potencial de estabelecimento da espécie baseados no índice ecoclimático (EI), que utiliza as seguintes exigências termicas da espécie: com estresse de temperatura, cenário mais restrito para a expansão; e sem estresse de temperatura. O EI foi classificado em quatro faixas: não favorável, $\leq 25 \%$; pouco favorável, $>25$ a $\leq 50 \%$; favorável, $>50$ a $\leq 75 \%$; e altamente favorável, $>75 \%$. As perdas econômicas foram estimadas a partir do mapa com a distribuição mais restritiva. As áreas consideradas altamente favoráveis foram sobrepostas às dos mapas de produção de cada hospedeiro possível (maçã, uva, pêssego, caqui, figo e pera). Ao se considerar esses seis hospedeiros, a sobreposição das áreas altamente favorável e de produção variou de 45,5\% (uva) a 98,3\% (maçã). No entanto, a estimativa monetária de perdas potenciais no pior cenário possível (sem medidas de controle) foi possível apenas para figo e pêssego. O Sul do Brasil é a área climaticamente mais favorável para o desenvolvimento de $D$. suzukii e onde as perdas econômicas potenciais podem ser máximas. As temperaturas médias máximas $\left(>30^{\circ} \mathrm{C}\right)$ são o principal fator para restringir a dispersão de D. suzukii no Brasil.
\end{abstract}

Termos para indexação: adaptação, biogeografia, bioinvasão, espécies exóticas, drosófila-da-asa-manchada.

\section{Introduction}

The dipterans of the Drosophilidae family encompass more than 4,000 species (Yassin, 2013). These flies breed on rotten fruit and other organic matter; however, the majority of them are not of economic importance. Only Zaprionus indianus (Gupta, 1970), the African fig fly, and Drosophila suzukii (Matsumura, 1931) (Diptera: Drosophilidae), are considered pests of economic relevance, because they are able to attack fruit suitable for human consumption prior to harvest (Van Timmeren \& Isaacs, 2014).

Drosophila suzukii became invasive in the second half of the $20^{\text {th }}$ century. It was first described in 1931 by Matsumura in Japan (Hauser, 2011). In the United States, it was collected in Hawaii in 1980, then in California in 2008 (Hauser, 2011), spreading across 
the western and eastern coasts of the country and of Canada. The species was also discovered in Spain in 2008, and in France in 2009, then spread to Central Europe and other countries on the Mediterranean coast, such as Slovenia and Croatia (Cini et al., 2014).

In Brazil, D. suzukii was reported for the first time in the subtropical forests of the southern region (Deprá et al., 2014), where it damaged strawberries in the municipality of Vacaria, in the state of Rio Grande do Sul (Santos, 2014). In the state of São Paulo, in the southeastern region, D. suzukii was found in fruits traded in a fruits and vegetable wholesale center (Vilela \& Mori, 2014). In addition, specimens of D. suzukii were collected in the Brazilian Cerrado (savannah-like vegetation), in Brasília, DF (Paula et al., 2014). This finding confirms that $D$. suzukii is able to spread until 1,400 km per year (Calabria et al., 2012).

Mathematical models for species distribution have been used to estimate the probability of an invasive species establishing itself in areas where it has not yet been found. Climex is one of the most used models to predict the potential geographic distribution of invasive species, such as Helicoverpa armigera (Lepidoptera: Noctuidae) in the United States (Kriticos et al., 2015) and Ceutorhynchus obstrictus (Coleoptera: Curculionidae), Meligethes viridescens (Coleoptera: Nitidulidae), and Oulema melanopus (Coleoptera: Chrysomelidae) in Canada (Olfert \& Weiss, 2006).

The potential spread of $D$. suzukii in Brazil is very significant, because more than $80 \%$ of the production areas of most of its hosts are located in climatically highly favorable areas. Restricting fruit trade in the internal market is a measure adopted to avoid the spread of this pest; however, it is not very effective due to the species' high natural spreading capability. This restriction could be more effective in unfavorable areas, such as important grape-production areas in the Northeast region of the country. It should be noted that economic evaluations are still necessary for any quarantine restriction.

The economic impact of D. suzukii has been described in the United States (Bolda et al., 2010; Goodhue et al., 2011) and in Italy (De Ros et al., 2013). The damaged fruits are considered unmarketable, and chemical control can result in the rejection of fruits for export and consumption due to insecticide residues (Haviland \& Beers, 2012). However, there is a lack of estimates of the economic losses caused by this pest around the world, which limits the analysis of costs and benefits for phytosanitary measures (Kehlenbeck et al., 2012).

The objective of this work was to outline the potential distribution and economic impact of D. suzukii, a recent invasive pest, in Brazil.

\section{Materials and Methods}

The simulated map of D. suzukii establishment was drawn using the Climex model (Hearne Software, Melbourne, Australia), which is based on information of the ecoclimate index (EI) on temperature thresholds for the development of a species. The index was determined by $\mathrm{EI}=\mathrm{GI} \times \mathrm{SI}$, in which GI is the growth index and SI is the stress index (Sutherst, 1991; Sutherst et al., 1999). Considering insects are poikilothermic and their development is mainly determined by temperature variation, it was assumed that $\mathrm{GI}=\mathrm{TI}$, in which TI is the temperature index, defined by the temperature limits (DV parameters) of the Climex model. For D. suzukii, the DV parameters considered were: limiting low temperature (DV0) of $7.2^{\circ} \mathrm{C}$; lower optimal temperature (DV1) of $13.4^{\circ} \mathrm{C}$; upper optimal temperature (DV2) of $28.1^{\circ} \mathrm{C}$; and limiting high temperature (DV3) of $30^{\circ} \mathrm{C}$. All temperature limits were based on data from Tochen et al. (2014). The number of degree-days for complete development is 208 (Table 1), i.e., the thermal constant $\mathrm{k}$ in positive degree-days (PDD) (Tochen et al., 2014).

In the model, when the average temperature is between DV1 and DV2, the value of the base temperature is subtracted from the average temperature in order to obtain degree-days. When the accumulated degree-days are positive (PDD), the model considers

Table 1. Parameter values used in the Climex software (Hearne Software, Melbourne, Australia) for the simulation of the potential distribution of Drosophila suzukii in Brazil.

\begin{tabular}{lcrc}
\hline Parameter & Code & Values & Reference \\
\hline Limiting low temperature & DV0 & 7.2 & Tochen et al. (2014) \\
Lower optimal temperature & DV1 & 13.4 & Tochen et al. (2014) \\
Upper optimal temperature & DV2 & 28.1 & Tochen et al. (2014) \\
Limiting high temperature & DV3 & 30.0 & Tochen et al. (2014) \\
Cold stress temperature threshold & TTCS & 5.0 & Kanzawa (1936) \\
Cold stress temperature rate & THCS & 0.001 & Sutherst et al. (1999) \\
Heat stress temperature threshold & TTHS & 30.0 & Kinjo et al. (2014) \\
Heat stress accumulation rate & THHS & 0.005 & Sutherst et al. (1999) \\
Degree-days per generation & PDD & 208.0 & Tochen et al. (2014) \\
\hline
\end{tabular}


that one development cycle was completed. Calculations of the number of generations per year were performed based on the thermal constant $\mathrm{k}$ (PDD).

Two environmental stress factors were considered for the SI: cold stress (THCS) and heat stress (THHS). ForTHCS, a temperature below $5^{\circ} \mathrm{C}$ is the limit for adult activity (Kanzawa, 1936); however, adults can survive in the winter with negative temperatures. For THHS, $30^{\circ} \mathrm{C}$ is the limit for larval eclosion and development (Kinjo et al., 2014). These two stress parameters were adjusted according to the Mediterranean template of Climex (Sutherst et al., 1999). When the minimum temperature is lower than the THCS value or the maximum temperature is higher than the THHS, the rhythm of organism development is decelerated at a rate provided by the model.

The Climex model uses a matrix of 61,076 terrestrial points, with distances of 0.5 degree among them. For each one of them there is data on minimum, average, and maximum temperatures, based on normal climatological variables between 1961 and 1990 (New et al., 2002). The EI was calculated combining TI and SI, and the maps were generated by the Dymex simulator software, using the "Compare Locations" function for one species of Climex, version 3.00.009 (Hearne Software, Melbourne, Australia).

For the species establishment maps, two scenarios were considered for Brazil: one with heat and cold stress, and the other without heat and cold stress. The EI was classified into four classes of favorability: unfavorable, $\leq 25 \%$, less than 3 months climatically favorable per year; less favorable, $>25$ to $\leq 50 \%$, between 3 to 6 months climatically favorable per year; favorable, $>50$ to $\leq 75 \%$, between 6 to 9 months climatically favorable per year; and highly favorable, $>75 \%$, more than 9 months climatically favorable per year.

Six D. suzukii hosts were evaluated: apple (Malus domestica Borkh.), fig (Ficus carica L.), grape (Vitis vinifera L.), peach [Prunus persica (L.) Batsch], pear (Pyrus communis L.), and persimmon (Diospyros kaki Thunb.).

Another map was drawn, showing the distribution of the production per municipality of the following $D$. suzukii hosts: apple, grape, peach, and persimmon. The data about these hosts were obtained from the statistics on production per municipality, "Produção Agrícola Municipal" (Instituto Brasileiro de Geografia e Estatística, 2013), and all the information was classified according to the fruit species and to production value. The two simulated maps - of D. suzukii potential distribution and of host production - were overlapped in order to observe regions with high phytosanitary risk (EI for D. suzukii $>75 \%$ ).

A partial budgeting method was used to estimate the potential economic impact of $D$. suzukii, employing a scenario without control measures (Soliman et al., 2010). The potential economic losses in monetary terms (values in US\$) were obtained through the equation: $\mathrm{L}_{(\$)}=\mathrm{PV}_{(\mathrm{hfa})} \times \mathrm{L}_{(\mathrm{r})}$, in which $\mathrm{L}_{(\$)}$ is the potential economic losses in monetary terms; $\mathrm{PV}\left({ }_{\mathrm{hfa}}\right)$ is the crop production value of the highly favorable area (EI $>75 \%$ ); and $\mathrm{L}_{(\mathrm{r})}$ is the maximum production loss reported without control measures $(\%)$.

\section{Results and Discussion}

The Climex parameters resulted in simulated distribution maps that are very similar to the real distribution of D. suzukii around the world, especially in North America, Europe, and Japan (Figure 1). In the United States, both the east and west coasts are suitable for the establishment of D. suzukii. This is similar to the information that was reported by Walsh et al. (2011). The obtained world map is also in alignment with current $D$. suzukii distribution across Europe (Cini et al., 2012) and Japan (Mitsui et al., 2010).

Most of Brazil is not favorable for the establishment of D. suzukii (EI $<25 \%)$ (Figure 1 and Table 2). However, states in the southern region are located in climatic areas that are considered favorable to highly favorable for D. suzukii establishment. The southeastern region, including the states of São Paulo and Minas Gerais, has more than $50 \%$ of its area classified as favorable or highly favorable. The average temperature of these areas is about $25^{\circ} \mathrm{C}$, which is favorable for the establishment of invasive species (Shi et al., 2010).

The two simulated maps, with temperature stress and without temperature stress, of predicted favorability in Brazil show some similarities and differences. In the scenario without stress, the spread of D. suzukii throughout Brazil would not be more extensive than that of the stress-restrictive scenario (Figures 2 and 3 ). The main difference between the scenarios is that the areas with intermediate favorability (EI $>25 \%$ to $<75 \%$ ) are predicted to be more extensive than those in the restrictive scenario. Therefore, the potential 
distribution of D. suzukii can occur somewhere between the two simulated scenarios.

The distribution limits of D. suzukii will be governed by the occurrence of average maximum temperatures above $30^{\circ} \mathrm{C}$. However, despite this temperature limit, the adaptation of $D$. suzukii to new environments and ecological niches might occur, although this process is not fast (Broennimann et al., 2007). Overall, the states of Rio Grande do Sul, Santa Catarina, Paraná, São Paulo, and Minas Gerais are located in regions that show a high probability of economic losses due to D. suzukii. These states are the main producers of grapes, apples, peaches, and persimmons (Figure 4). Other D. suzukii hosts, such as strawberry (Fragaria vesca L.), raspberry (Rubus idaeus L.), and mulberry (Morus sp.), were not considered in the economic impact study because there is no data available concerning production per municipality (Instituto Brasileiro de Geografia e Estatística, 2013). However, these hosts are still important. In 2013, for example, 9,708 $\mathrm{Mg}$ of strawberry were marketed by the fruits and vegetable wholesale center "Companhia de Entrepostos e Armazéns Gerais de São Paulo" (Ceagesp) at the price of R\$ 10.00 per kilogram (Agrianual..., 2015), indicating losses of $30 \%$ in production (Santos, 2014), which would mean R\$ 29 million or US\$ 11.5 million. The potential economic losses of peaches and figs were 20 and $30 \%$ according to data from Lies (2009) and from Berry (2012), respectively, representing a Figure of about US\$29.2 million or R\$ 75.9 million as maximum potential economics losses caused by D. suzukii in Brazil (Table 3). It should be highlighted that yield losses estimated in $20 \%$ must be considered only an average benchmark (Bolda et al., 2010), which is a critical simplifying assumption (Goodhue et al., 2011). An analysis based on price response reduces estimated losses, but the inclusion of managing costs on market prices is not possible due to the lack of identification of suitable control approaches (Goodhue et al., 2011). In this scenario, a powerful tool for economic analysis, such as partial equilibrium modeling (Soliman et al., 2010), cannot be used to estimate losses of D. suzukii in Brazil. Despite showing limitations for a precise estimation of losses, predicted monetary values for economic impact assessment of invasive pests are very useful for cost-benefit analysis of pest eradication programs (Miranda et al., 2015).

In spite of the available statistics for grape, apple, pear, and persimmon production in Brazil, there is no data about losses caused by D. suzukii around the world. It is probable that potential losses are lower than those reported for small fruits. The production value of these four fruits is of $\mathrm{R} \$ 3.87$ billion or US\$ 1.49 billion (Instituto Brasileiro de Geografia e

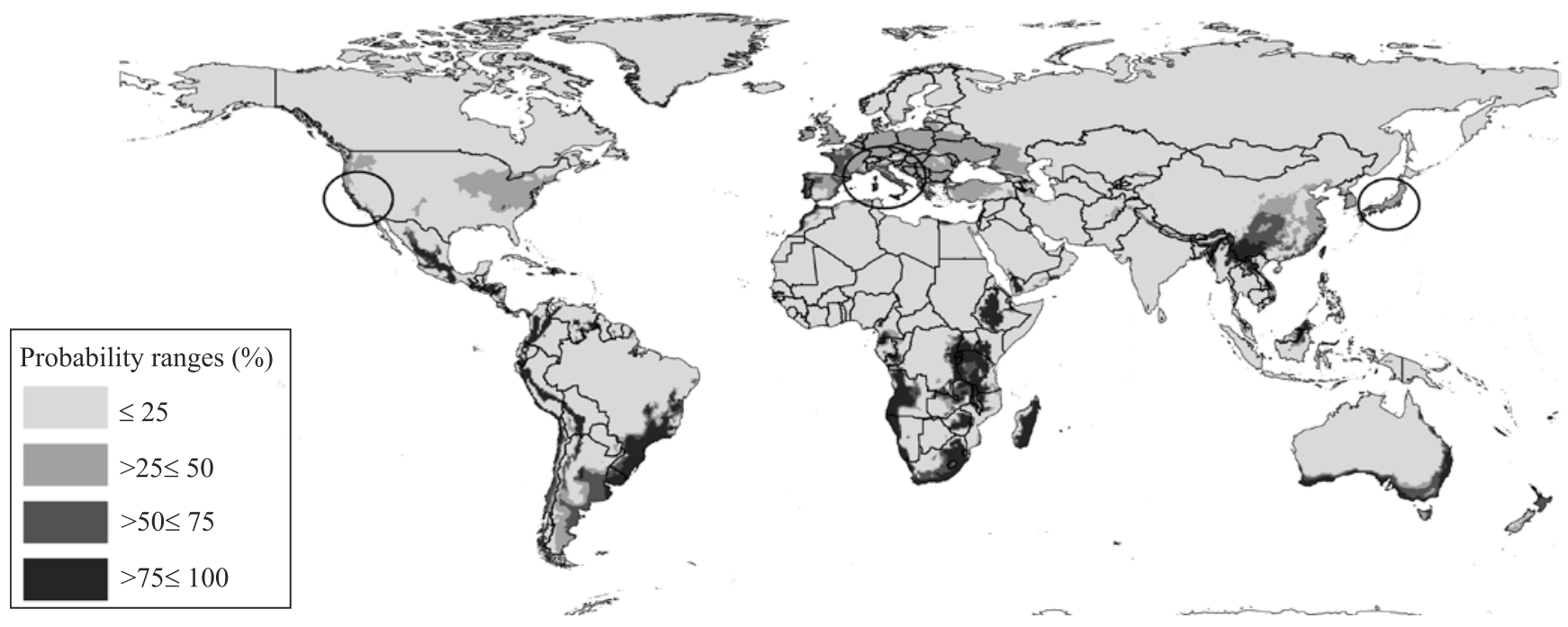

Figure 1. Potential distribution of Drosophila suzukii around the world. Areas in circles are regions where D. suzukii occurred before it was registered in Brazil. USA, according to Walsh et al. (2011); Europe, Cini et al. (2012); and Japan, Mitsui et al. (2010). 
Estatística, 2014). Brazilian apple production is almost entirely located in highly favorable areas for $D$. suzukii establishment, whereas grape production is located in less than half of the highly favorable areas for D. suzukii (Table 2). However, highly favorable areas for D. suzukii account for $90 \%$ of the grape production area in South Brazil, mainly in the states of Rio Grande do Sul, Santa Catarina, and Paraná, and for $45 \%$ of the grape production area in the state of São Paulo. The São Francisco Valley, the most important area of grape

Table 2. Percentage distribution of occupied area according to the classes of climatic favorability for Drosophila suzukii establishment in Brazil and in five states.

\begin{tabular}{lcccc}
\hline Location & \multicolumn{4}{c}{ Classes of climatic favorability for D. suzukii (\%) } \\
\cline { 2 - 5 } & $\leq 25$ & $>25 \leq 50$ & $>50 \leq 75$ & $>75$ \\
\hline Brazil & 79 & 5 & 5 & 11 \\
Rio Grande do Sul & 5 & 7 & 23 & 65 \\
Santa Catarina & 0 & 0 & 3 & 97 \\
Paraná & 3 & 1 & 14 & 82 \\
São Paulo & 19 & 11 & 15 & 55 \\
Minas Gerais & 25 & 21 & 19 & 35 \\
\hline
\end{tabular}

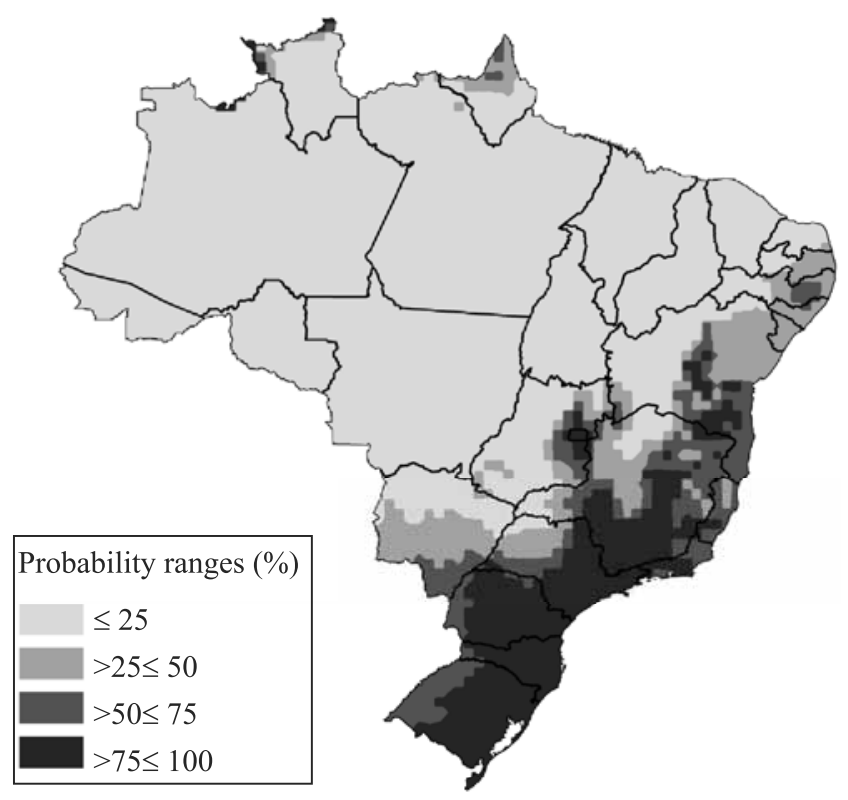

Figure 2. Map of predicted climatic favorability for Drosophila suzukii establishment in Brazil in a scenario without temperature stress. Probability ranges are temperature intervals of the ecoclimatic index from Climex (Hearne Software, Melbourne, Australia). The darkest areas are highly favorable for D. suzukii establishment. production in the states of Bahia and Pernambuco, in Northeast Brazil, is a climatically unsuitable area for D. suzukii, even in simulated scenarios without temperature stress.

Considering a hypothetical "worst case scenario" -D. suzukii spreads to all climatically suitable areas in Brazil and no control measures are adopted -, fruit production in the state of Rio Grande do Sul would experience the greatest economic impact. Southeastern and northeastern Rio Grande de Sul are areas that concentrate the majority of preferential hosts for D. suzukii. This impact could be expected based on the fact that, in the United States, D. suzukii is adding a cost between US\$ 250 to US\$ 350 per acre (Werts \& Green, 2014). Producers of small fruits have been the most affected in economic terms. Before D. suzukii invasion, small fruit growers from Oregon spent US\$ 1 million on pest management, and, after the invasion, this aggregated cost increased to US\$ 15 million in 2013 (Werts \& Green, 2014). One of the aspects that has relevance in order to quantify the impact

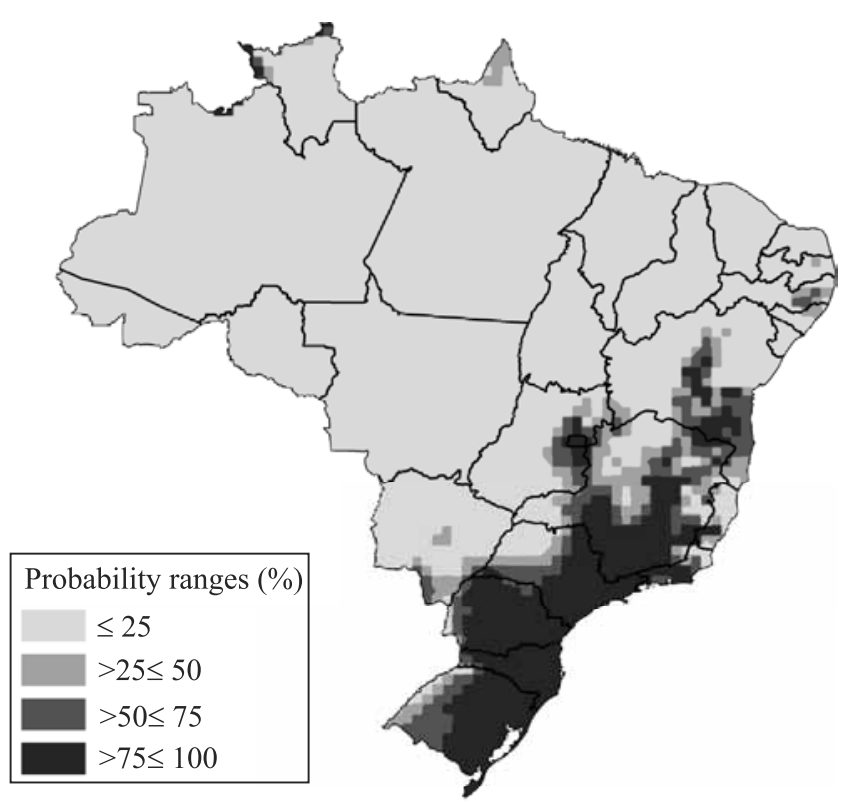

Figure 3. Map of predicted climatic favorability for Drosophila suzukii establishment in Brazil in a scenario with temperature stress. Probability ranges are the temperature intervals of the ecoclimatic index from Climex (Hearne Software, Melbourne, Australia). The darkest areas are highly favorable for D. suzukii establishment. 
of D. suzukii is that the species is broadening its host range in new environments. This adaptation to new hosts is inferred based on the first records of D. suzukii in Brazil in forest reserves (Santos, 2014).

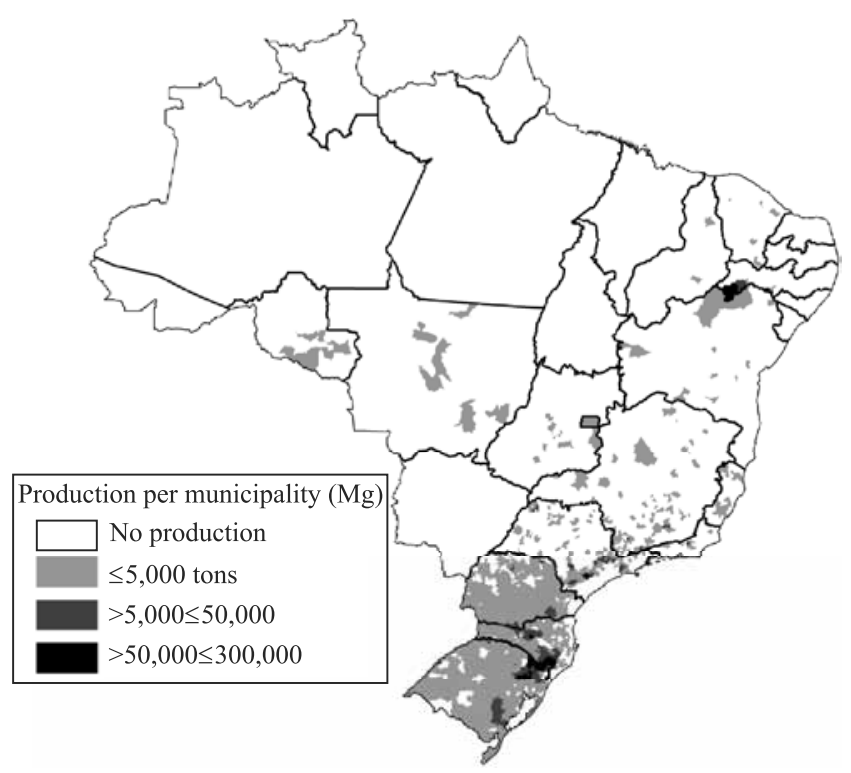

Figure 4. Aggregated production per municipality $(\mathrm{Mg})$ of four D. suzukii hosts: grape (Vitis vinifera), apple (Malus domestica), peach (Prunus persica), and persimmon (Diospyros kaki). Source: Instituto Brasileiro de Geografia e Estatística (2013).

Table 3. Estimation of production value and maximum potential losses for Drosophila suzukii in six hosts plants in Brazil $^{(1)}$.

\begin{tabular}{lccccc}
\hline Crop & $\begin{array}{c}\text { Production } \\
\text { (US\$ } \\
\text { million) }\end{array}$ & $\begin{array}{c}\text { HFA/PA } \\
(\%)\end{array}$ & $\begin{array}{c}\text { HFA } \\
\text { (US\$ } \\
\text { million) }\end{array}$ & $\begin{array}{c}\text { Potential } \\
\text { losses } \\
(\%)\end{array}$ & $\begin{array}{c}\text { Potential } \\
\text { losses (US\$ } \\
\text { million) }\end{array}$ \\
\hline $\begin{array}{l}\text { Grape (Vitis } \\
\text { vinifera) }\end{array}$ & 850 & 45.5 & 387 & - & - \\
$\begin{array}{l}\text { Apple (Malus } \\
\text { domestica) }\end{array}$ & 533 & 98.3 & 524 & - & - \\
$\begin{array}{l}\text { Peach (Prunus } \\
\text { persica) }\end{array}$ & 128 & 83.3 & 107 & 20 & 21.4 \\
$\begin{array}{l}\text { Persimmon } \\
\text { Diospyros kaki) }\end{array}$ & 96 & 92.3 & 89 & - & - \\
$\begin{array}{l}\text { Fig (Ficus } \\
\text { carica) }\end{array}$ & 29 & 89.7 & 26 & 30 & 7.8 \\
$\begin{array}{l}\text { Pear (Pyrus } \\
\text { communis) }\end{array}$ & 13 & 83.3 & 11 & - & - \\
\hline
\end{tabular}

(1)HFA, highly favorable area, according to the ecoclimatic index $>75 \%$ (Climex, Hearne Software, Melbourne, Australia); PA, production area; and -, data not available. Exchange rate: US\$ $1=R \$ 2,60$ on December, $9^{\text {th }}$, 2014, according to Banco Central do Brasil (2015).
The population dynamics of $D$. suzukii may be affected by the fructification patterns of wild hosts. Moreover, the abundance of D. suzukii in orchards will depend on how well the food resources provided by the wild hosts can sustain populations in natural areas. Expected adaptation to new hosts (cultivated and native) in short term may allow D. suzukii to spread in all areas favorable for its development, in which its population might be forming a continuum (Hauser, 2011; Maier, 2012). As a parallel example, the invasive drosophilid $Z$. indianus is undergoing niche shift after colonization of new areas around the world (Mata et al., 2010). In this case, potential distribution areas can be inferred based on the new locations in which the organism establishes itself.

Considering that the population fluctuation of D. suzukii depends on food resources and temperatures, an inference may be made using population data from other drosophilids. Some vinegar flies, such as Drosophila melanogaster, Drosophila nigricuria, and Drosophila cardinoides, are found in the Pampas region of the state of Rio Grande do Sul. These species are more abundant between June and September, when minimum and maximum average temperatures are between 10 and $25^{\circ} \mathrm{C}$ (Poppe et al., 2013). These temperatures are close to the temperature limits, and these four months will probably be the most favorable. Therefore, this short season of most favorable conditions may decrease the potential economic impact of D. suzukii.

In general, it will be necessary to develop some management options in order to control D. suzukii, with constant surveillance and monitoring during some years. Control measures can be applied based on solid scientific information in the case of phytosanitary emergencies caused by $D$. suzukii.

\section{Conclusions}

1. South Brazil is the region that shows the most climatically favorable areas for Drosophila suzukii establishment.

2. Maximum average temperatures $\left(>30^{\circ} \mathrm{C}\right)$ are the main ecological factors to limit $D$. suzukii spread in Brazil. 


\section{References}

AGRIANUAL 2015: anuário da agricultura brasileira. 20.ed. São Paulo: FNP, 2015. 472p.

BANCO CENTRAL DO BRASIL. Banco Central do Brasil. Disponível em: <http:/www.bcb.gov.br/pt-br/\#!/home>. Acesso em: 24 mar. 2015.

BERRY, J.A. Pest risk assessment: Drosophila suzukii: spotted wing drosophila (Diptera: Drosophilidae) on fresh fruit from the USA.Wellington: Ministry for Primary Industries, 2012. 46p. Final: MPI Technical paper n. ${ }^{\circ}$ 2012/05.

BOLDA, M.P.; GOODHUE, R.E.; ZALOM, F.G. Spotted wing drosophila: potential economic impact of newly established pest. Giannini Foundation of Agricultural Economics, v.13, p.5-8, 2010 .

BROENNIMANN, O.; TREIER, U.A.; MÜLLER-SCHÄRER, H.; THUILLER, W.; PETERSON, A.T.; GUISAN, A. Evidence of climatic niche shift during biological invasion. Ecology Letters, v.10, p.701-709, 2007. DOI: 10.1111/j.1461-0248.2007.01060.x.

CALABRIA, G.; MÁCA, J.; BÄLICH, G.; SERRA, L.; PASCUAL, M. First records of the potential pest species Drosophila suzukii (Diptera: Drosophilidae) in Europe. Journal of Applied Entomology, v.136, p.139-147, 2012. DOI: 10.1111/j.1439-0418 .2010.01583.x.

CINI, A.; ANFORA, G.; ESCUDERO-COLOMAR, L.A.; GRASSI, A.; SANTOSUOSSO, U.; SELJAK, G.; PAPINI, A. Tracking the invasion of the alien fruit pest Drosophila suzukii in Europe. Journal of Pest Science, v.87, p.559-566, 2014. DOI: 10.1007/s10340-014-0617-z.

CINI, A.; IORIATTI, C.; ANFORA, G. A review of the invasion of Drosophila suzukii in Europe and a draft research agenda for integrated pest management. Bulletin of Insectology, v.65, p.149-160, 2012.

DE ROS, G.; ANFORA, G.; GRASSI, A.; IORIATTI, C. The potential economic impact of Drosophila suzukii on small fruits production in Trentino (Italy). Integrated Protection of Fruit Crops, v.91, p.317-321, 2013.

DEPRÁ, M.; POPPE, J.L.; SCHMITZ, H.J.; DE TONI, D.C.; VALENTE, V.L.S. The first records of the invasive pest Drosophila suzukii in the South American continent. Journal of Pest Science, v.87, p.379-383, 2014. DOI: 10.1007/s10340-014-0591-5.

GOODHUE, R.E.; BOLDA, M.; FARNSWORTH, D.; WILLIAMS, J.C.; ZALOM, F.G. Spotted wing drosophila infestation of California strawberries and raspberries: economic analysis of potential revenue losses and control costs. Pest Management Science, v.67, p.1396-1402, 2011. DOI: 10.1002/ps.2259.

HAUSER, M. A historic account of the invasion of Drosophila suzukii (Matsumura) (Diptera: Drosophilidae) in the continental United States, with remarks on their identification. Pest Management Science, v.67, p.1352-1357, 2011. DOI: 10.1002/ ps. 2265 .

HAVILAND, D.R.; BEERS, E.H. Chemical control programs for Drosophila suzukii that comply with international limitations on pesticide residues for exported sweet cherries. Journal of
Integrated Pest Management, v.3, p.F1-F6, 2012. DOI: 10.1603/ IPM11034.

INSTITUTO BRASILEIRO DE GEOGRAFIA E ESTATÍSTICA. Produção agrícola municipal. 2013. Disponível em: <http:// downloads.ibge.gov.br/downloads_estatisticas.htm>. Acesso em: 8 jul. 2014.

INSTITUTO BRASILEIRO DE GEOGRAFIA E ESTATÍSTICA. Produção agrícola municipal. 2014. Disponível em: <http:// www.sidra.ibge.gov.br/bda/agric/>. Acesso em: 3 nov. 2015.

KANZAWA, T. Studies on Drosophila suzukii Mats. Journal of Plant Protection, Tokyo, v.23, p.66-70, 1936.

KEHLENBECK, H.; ROBINET, C.; WERF, W. VAN DER; KRITICOS, D.; REYNAUD, P.; BAKER, R. Modelling and mapping spread in pest risk analysis: a generic approach. EPPO Bulletin, v.42, p.74-80, 2012. DOI: 10.1111/j.1365-2338.2012.02 550.x.

KINJO, H.; KUNIMI, Y.; NAKAI, M. Effects of temperature on the reproduction and development of Drosophila suzukii (Diptera: Drosophilidae). Applied Entomology and Zoology, v.49, p.297-304, 2014. DOI: 10.1007/s13355-014-0249-z.

KRITICOS, D.J.; OTA, N.; HUTCHISON, W.D.; BEDDOW, J.; WALSH, T.; TAY, W.T.; BORCHERT, D.M.; PAULA-MORAES, S.V.; CZEPAK, C.; ZALUCKI, M.P. The potential distribution of invading Helicoverpa armigera in North America: is it just a matter of time? PLoS One, v.10, p.1-24, 2015. DOI: 10.1371/ journal.pone.0119618.

LIES, M. New fruit pest triggers concerns. Capital Press Agricultural News, 26 Sept. 2009. Available at: <http://www. capitalpress.com/content/ml-vinegar-fly-092509-art\#>. Accessed on: 25 Mar. 2014.

MAIER, C.T. First detection and widespread distribution of the spotted wing drosophila, Drosophila suzukii (Matsumura) (Diptera: Drosophilidae), in Connecticut in 2011. Proceedings of the Entomological Society of Washington, v.114, p.329-337, 2012. DOI: $10.4289 / 0013-8797.114 .3 .329$.

MATA, R.A. da; TIDON, R.; CÔRTES, L.G.; DE MARCO JR., P.; DINIZ-FILHO, J.A.F. Invasive and flexible: niche shift in the drosophilid Zaprionus indianus (Insecta, Diptera). Biological Invasions, v.12, p.1231-1241, 2010. DOI: 10.1007/ s10530-009-9542-0.

MIRANDA, S.H.G.; NASCIMENTO, A.M.; XIMENES, V.P. Potenciais impactos socioeconômicos da expansão da mosca-da-carambola. In: VILELA, E.F.; ZUCCHI, R.A. (Ed.). Pragas introduzidas no Brasil: insetos e ácaros. Piracicaba: FEALQ, 2015. p.132-149.

MITSUI, H.; BEPPU, K.; KIMURA, M.T. Seasonal life cycles and resource uses of flower- and fruit-feeding drosophilid flies (Diptera: Drosophilidae) in central Japan. Entomological Science, v.13, p.60-67, 2010. DOI: 10.1111/j.1479-8298.2010.0 0372.x.

NEW, M.; LISTER, D.; HULME, M.; MAKIN, I. A high-resolution data set of surface climate over global land areas. Climate Research, v.21, p.1-25, 2002. DOI: 10.3354/cr021001.

OLFERT, O.; WEISS, R.M. Impact of climate change on potential distributions and relative abundances of Oulema melanopus, 
Meligethes viridescens and Ceutorhynchus obstrictus in Canada. Agriculture, Ecosystems and Environment, v.113, p.295-301, 2006. DOI: 10.1016/j.agee.2005.10.017.

PAULA, M.A.; LOPES, P.H.S.; TIDON, R. First record of Drosophila suzukii in the Brazilian Savanna. Drosophila Information Service, v.97, p.113-115, 2014.

POPPE, J.L.; VALENTE, V.L.S.; SCHMITZ, H.J. Population dynamics of drosophilids in the Pampa biome in response to temperature. Neotropical Entomology, v.42, p.269-277, 2013. DOI: $10.1007 / \mathrm{s} 13744-013-0125-5$.

SANTOS, R.S.S. dos. Ocorrência de Drosophila suzukii (Matsumura, 1931) (Diptera: Drosophilidae) atacando frutos de morango no Brasil. Bento Gonçalves: Embrapa Uva e Vinho, 2014. 4p. (Embrapa Uva e Vinho. Comunicado técnico, 159).

SHI, J.; LUO, Y.-Q.; ZHOU, F.; HE, P. The relationship between invasive alien species and main climatic zones. Biodiversity and Conservation, v.19, p.2485-2500, 2010. DOI: 10.1007/ s10531-010-9855-4.

SOLIMAN, T.; MOURITS, M.C.M.; OUDE LANSINK, A.G.J.M.; WERF, W. van der. Economic impact assessment in pest risk analysis. Crop Protection, v.29, p.517-524, 2010. DOI: 10.1016/j. cropro.2009.12.014.

SUTHERST, R.W. Predicting the survival of immigrant insect pests in new environments. Crop Protection, v.10, p.331-333, 1991. DOI: 10.1016/S0261-2194(06)80020-7.

SUTHERST, R.W.; MAYWALD, G.F.; YONOW, T.; STEVENS, P.M. Climex: predicting the effects of climate on plants and animals: user guide. Collingwood: Commonwealth Scientific and Industrial Research Organisation, 1999. 88p.

TOCHEN, S.; DALTON, D.T.; WIMAN, N.; HAMM, C; SHEARER, P.W.; WALTON, V.M. Temperature-related development and population parameters for Drosophila suzukii (Diptera: Drosophilidae) on cherry and blueberry. Environmental Entomology, v.43, p.501-510, 2014. DOI: 10.1603/EN13200.

VAN TIMMEREN, S.; ISAACS, R. Drosophila suzukii in Michigan vineyards, and the first report of Zaprionus indianus from this region. Journal of Applied Entomology, v.138, p.529-537, 2014. DOI: $10.1111 /$ jen. 12113 .

VILELA, C.R.; MORI, L. The invasive spotted-wing Drosophila (Diptera, Drosophilidae) has been found in the city of São Paulo (Brazil). Revista Brasileira de Entomologia, v.58, p.371-375, 2014. DOI: $10.1590 / \mathrm{S} 0085-56262014000400004$.

WALSH, D.B.; BOLDA, M.P.; GOODHUE, R.E.; DREVES, A.J.; LEE, J.; BRUCK, D.J.; WALTON, V.M.; O’NEAL, S.D.; SALOM, F.G. Drosophila suzukii (Diptera: Drosophilidae): invasive pest of ripening soft fruit expanding its geographic range and damage potential. Journal of Integrated Pest Management, v.106, p.289-295, 2011. DOI: 10.1603/ipm10010.

WERTS, P.; GREEN, T. Spotted wing drosophila: adding cost to fruit production. Crops and Soils, v.47, p.36-38, 2014.

YASSIN, A. Phylogenetic classification of the Drosophilidae Rondani (Diptera): the role of morphology in the postgenomic era. Systematic Entomology, v.38, p.349-364, 2013. DOI: 10.1111/j.1 365-3113.2012.00665.x.

Received on January 06, 2015 and accepted on December 17, 2015 